\title{
Soil salinity assessment from satellite data in the Trans-Ural steppe zone (Southern Ural, Russia)
}

\author{
Azamat Suleymanov $^{1 *}$, Ilyusya Gabbasova ${ }^{1}$, Evgeny Abakumov², Jakub Kostecki \\ ${ }^{1}$ Ufa Institute of Biology, Ufa Federal Research Centre, Russian Academy of Sciences, Department of Soil Science, pr. Oktyabrya 69, 450054 Ufa, \\ Russia \\ ${ }^{2}$ Saint Petersburg State University, Department of Applied Ecology, Universitetskaya nab 7-9, 199034 Saint Petersburg, Russia \\ ${ }^{3}$ University of Zielona Góra, Institute of Environmental Engineering, 15 Prof. Z. Szafrana St., 65-516 Zielona Góra, Poland \\ * Junior researcher, postgraduate student, A. Suleymanov, filpip@yandex.ru, +79178085019, ORCID iD: https://orcid.org/0000-0001-7974-4931
}

\begin{abstract}
Received: 25.05.2020

Accepted: 07.01.2021

Associated editor: P. Hulisz

Keywords

Salinization

Dry residue of soil

Spectral indices

Space data

Sentinel

Soil salinization is an up-to-date worldwide issue. This problem is especially urgent in the territories of arid and semi-arid regions. The aim of this work was to analyze the relationships between the level of soil salinity and the key spectral indices obtained on the base of Sentinel-2A satellite data. The study has been conducted on an area of 5127 ha in the Trans-Ural steppe zone (Republic of Bashkortostan, Russia). Vegetation index NDVI and 15 salinity indices have been used to analyze the relationships. Salinity index III ( $\mathrm{G} \times \mathrm{R}) / \mathrm{B}$ using quadratic statistical relation showed the best correlation values with a salinity level $\left(\mathrm{R}=0.89, \mathrm{R}^{2}=0.79\right)$. In general, it was found that the highest correlation values are observed with indices based on the three channels of visible range: Salinity index 2 $\sqrt{ }(G \times R)\left(R=0.82, R^{2}=0.67\right)$, Salinity index $4 \sqrt{ }\left(G^{2}+R^{2}\right)\left(R=0.82, R^{2}=0.67\right)$, Salinity index VII $(G+R) / 2$ $\left(\mathrm{R}=0.82, \mathrm{R}^{2}=0.67\right)$. The vegetation index NDVI showed the absence of a correlation with the values $\left(R=-0.10, R^{2}=0.01\right)$, due to weak development or dry state of vegetation. The areas of saline soils using Salinity index III were calculated. The methods elaborated could be useful for mapping and accounting of saline soils based on satellite data under environmental conditions similar to this study.
\end{abstract}

\section{Introduction}

Salinization of soils is considered as one of the main factors of land degradation and desertification in arid and semiarid regions of subboreal and subtropic belts of the world (Metternicht and Zinck, 2003; Abuelgasim and Ammad, 2019). Saline soils are predominantly located in the southern regions of Russia. In these regions, agriculture is extensively developed and occupies the most lands of the country (Pankova, 2015). The Republic of Bashkortostan is one of the leading and developing agricultural regions of Russia and possesses 3.3\% (7.326 thousand ha, arable land -3670.5 thousand ha) of agricultural lands of the country (Rosreestr, 2018).

According to Pankova et al (2017), the territory of the Republic of Bashkortostan is classified as the zone of spreading of saline soils within agricultural lands. Nevertheless, natural saline soils are mainly distributed in the Trans-Ural steppe zone. This area is relatively small and amounts to about 60 thousand ha (Khaziev, 1995). In this context, the problem of soil salinization in the region has not been analyzed enough. Only the works of P.Ya. Bulchuk are known (1966; 1973), who determined that their genesis is relict and is conditioned by the composition of parental rocks and mineralized groundwaters. In the last 20 years, studies of salinization processes in the region have been carried out mainly for soil contamination with crude oil, byproduct brines (Khaziev et al., 2001; Gabbasova et al., 2007; Gabbasova and Suleimanov, 2013) and under irrigation conditions (Gabbasova et al., 2006).

At the same time, global climate change consequences have been identified in the republic: based on the analysis of climatic data since 1881 the increase of average monthly and average annual air temperatures, decrease of average annual precipitation amounts in forest-steppe, and mountain-forest zones in the republic have been revealed (Sobol et al., 2015). In the Trans-Ural steppe zone, according to data of Abdrakhmanov and Popov (2010), the average long-term temperature in 1994-2008 compared to the period $1937-2008$ increased by $1^{\circ} \mathrm{C}$. Moreover, precipitation decreased by $20.8 \mathrm{~mm}$ per year, and the number of years with prolonged droughts during the growing season increased (Komissarov et al., 2019), i.e., the preconditions for aridization are obvious.

The intensity of spontaneous wild-fires is increasing in Russia and Bashkortostan lately (Kattsov, 2017). Natural wild-fires lead to an increase in the content of water-soluble salts and exchangeable sodium (Gabbasova et al., 2019). The mentioned factors indicate an increase in the mineralization and alkalinity of 
groundwaters, magnification risk of soil salinization processes, as well as desertification of steppe landscapes.

Salinization is a dynamic process that requires constant accounting field surveys and monitoring (Metternichet and Zinck, 2003; Khan et al., 2005; Gorji et al., 2017; Pankova et al., 2017; Masoud et al., 2019; Wang et al., 2019). Compared to traditional methods, remote research methods are faster, more cost-effective, and can cover large areas. They are increasingly used in studies and mapping of soil properties (Mulder et al., 2011; Ivushkin et al., 2018; Savin et al., 2019). When using satellite data, various spectral indices (salinity, brightness, vegetation indices) calculated based on a combination of satellite channels are widely developed and applied. This is facilitated by the improvement of satellite image quality (spatial resolution), large data set (longterm image archives), short imagery interval, free access to space images (Metternichet and Zinck, 2003; Allbed and Kumar, 2013).

Dry residue remnants - total content of mineral and organic substances in water extraction from soil. Dry residue soil fairly accurately characterizes the level of soil salinization and is its key element. Regression analysis of soil salinity data and spectral indices make it possible to assess the degree of salinity and mapping saline soils (Allbed et al., 2014; Wu et al., 2014; Taghadosi et al., 2019). New studies at local and regional levels based on modern methods are required for complete evaluation of salinization and development of actual cartographic materials.

These challenges are especially relevant for correcting and digitizing soil maps. This work aims to analyze the relationship between the dry residue of soil and main spectral salinity indices obtained from data of Sentinel-2A satellite, as well as to assess the salinity of soil and mapping study area of the Trans-Ural steppe.

\section{Material and Methods}

Research has been conducted in the Trans-Ural steppe zone in the territory of the Khaibulinsky district of Bashkortostan Republic (Fig. 1). The area of the investigated site is about 5127 hectares with height differences from 300 to $350 \mathrm{~m}$. Several water reservoirs are located on the territory. „Mambetovo” is located in the southern part. This reservoir with an area of about 100 hectares was constructed in 2005. In the northern part there are two reservoirs of about 4 ha each, and small ponds in different parts of the area.

The climate of the area is arid and extreme continental and, as noted above, there is an increase in aridization. Soil-forming sediments are mainly diluvial yellow-brown carbonate clays and heavy loams. Soil cover is composed mainly by chernozems with low content of total organic matter.

Salt-affected soils (solonetz and solonchak) do not form separate areas and belong to the sulfate, chloride-sulfate, and mixed type of salinization. These soils are mainly combined with soils of chernozem type. The formation of solonetz and solonchak is facilitated by a high content of readily soluble salts from the tertiary seas and the arid climate of the territory (Bulchuk, 1973).

The key soil types of the area were identified by satellite images and soil maps. The different soils have different colors and spectral reflectivity. Therefore, the soil samples were collected on different soil types in comparison with select reference samples. The exact coordinates of each soil point were identified using a global positioning system (GPS) with an accuracy of $\pm 3 \mathrm{~m}$. The points coordinates were imported in a tablet computer with a GPS function and used to find a point in the investigated area. A total of 52 topsoil samples were collected under dry conditions at a depth of 0-10 cm in August-September 2018 and 2019. The soil sampling work was carried out in areas with natural vegetation. The scheme of points locations are shown on the map (Fig. 1).

Due to zero content of carbonates and gypsum in the upper 0-10 cm layer of chernozem, we used the most traditional in Russia 1:5 water extracts to determine the water content of salts. (Pankova et al., 2006, 2015; Khitrov et al., 2016; Gorokhova et al., 2018; Balyuk et al., 2019). The solonchaks, like the most saline soils, are characterized by an absence of vegetation and have a very light color surface (salt crust). In such soils, salt content in the $1: 5$ extract is overestimated. Nevertheless, since the content of salts in these soils varies over a wide range (up to 5.5\%) and is classified as extremely high (more than $2 \%$ ), this excess will not significantly affect the reflectivity and this error can be ignored.

The total content of readily soluble salts (dry residue) of soil was determined in laboratory conditions by $1: 5$ soil water extracts. All collected samples were air-dried, homogenized, and

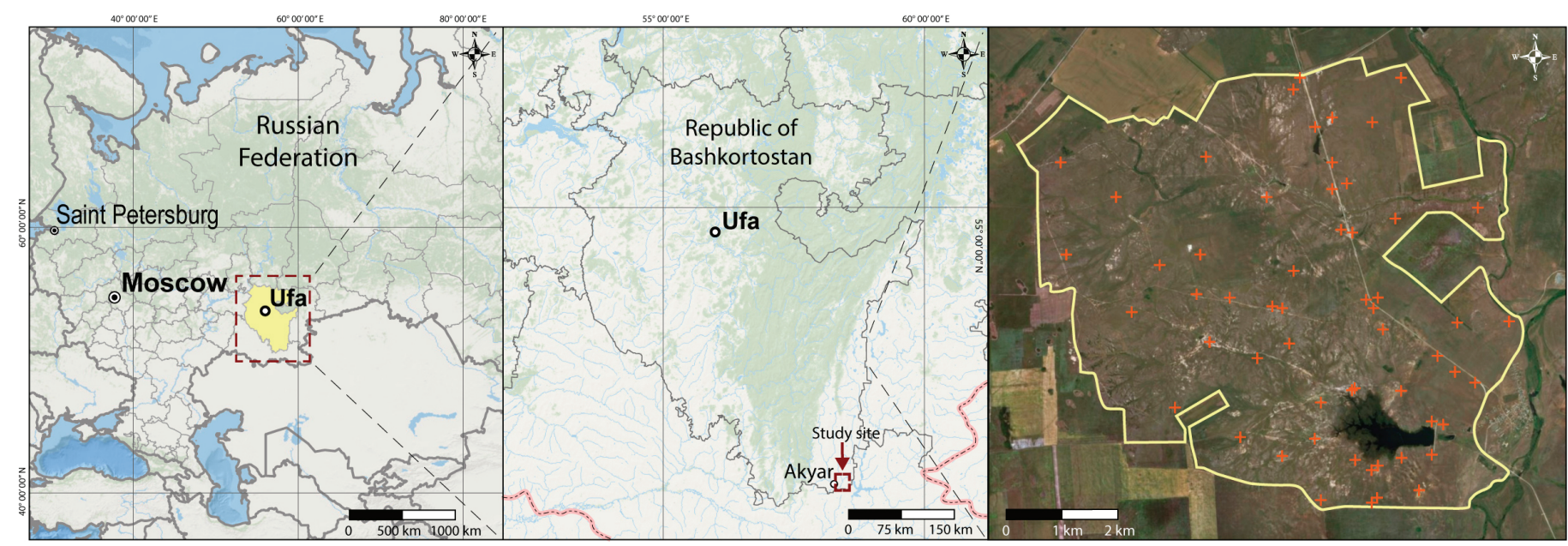

Fig. 1. Location of the investigated area 
sieved to $1 \mathrm{~mm}$. Then $100 \mathrm{~g}$ of soil was poured by $500 \mathrm{ml}$ of carbon dioxide-free water, mixed for 3 minutes, and filtered. The results of the soil-water extracts in the amounts of $25 \mathrm{ml}$ were evaporated, dried in predetermined weight cups, and weighed. Soil salinity was assessed by the criteria (Mamontov, 2002) (Table 1).

Cloud-free Sentinel-2A satellite images were downloaded from Copernicus Open Access Hub (https://scihub.copernicus. eu/dhus/\#/home). The satellite data contains 13 spectral channels

Table 1

Soil salinization range (Mamontov 2002)

\begin{tabular}{ll}
\hline Degree of soil salinization & Dry residue, \% \\
\hline Non-saline & $<0,25$ \\
Slightly saline & $0,25-0,50$ \\
Moderately saline & $0,50-1,00$ \\
Highly saline & $1,00-2,00$ \\
Extremely saline & $>2,00$ \\
\hline
\end{tabular}

with spatial resolution from 10 to $60 \mathrm{~m}$. Scenes from 22.09.2018 were selected for the best possible comparison of field and space data. Satellite data processing and cartographic materials creation was carried out in QGIS 3.6.0 geographic information system. Inputs to the atmospheric correction algorithm are shown in Table 2. Spectral indices calculated and used in the work based on the Sentinel-2A satellite channel combination are presented in Table 3.

Table 2

Input parameters for atmospheric correction algorithm

\begin{tabular}{ll}
\hline Input parameter & Value \\
\hline Terrain Elevation & $0.315 \mathrm{~km}$ \\
Local Time of Acquisition & $07: 06: 16$ \\
Acquisition Date & $2018 / 09 / 22$ \\
Solar Zenith Angle & 52.47553 \\
Solar Azimuth Angle & 165.29121 \\
Atmospheric model & Mid Lat Summer \\
Aersol model & Rural \\
Horizontal visibility & $50 \mathrm{~km}$ \\
Water Vapor & $2 \mathrm{~g} / \mathrm{cm}^{2}$ \\
\hline
\end{tabular}

Table 3

Calculated spectral indices for soil salinity mapping

\begin{tabular}{|c|c|c|c|c|}
\hline Acronym & Spectral index & Formula & Equation for Sentinel 2 & Source \\
\hline SI 1 & Salinity index 1 & $\sqrt{\mathrm{B} \times \mathrm{R}}$ & $\sqrt{\mathrm{B} 2 \times \mathrm{B} 4}$ & Khan et al. 2005 \\
\hline SI 2 & Salinity index 2 & $\sqrt{\mathrm{G} \times \mathrm{R}}$ & $\sqrt{\mathrm{B} 3 \times \mathrm{B} 4}$ & Khan et al. 2005 \\
\hline SI 3 & Salinity index 3 & $\sqrt{\mathrm{G}^{2}+\mathrm{R}^{2}+\mathrm{NIR}^{2}}$ & $\sqrt{(\mathrm{B} 3)^{2}+(\mathrm{B} 4)^{2}+(\mathrm{B} 8)^{2}}$ & Douaoui et al. 2006 \\
\hline SI 4 & Salinity index 4 & $\sqrt{G^{2}+R^{2}}$ & $\sqrt{(\mathrm{B} 3)^{2}+(\mathrm{B} 4)^{2}}$ & Douaoui et al. 2006 \\
\hline BI & Brightness index & $\sqrt{\mathrm{R}^{2}+\mathrm{NIR}^{2}}$ & $\sqrt{(\mathrm{B} 4)^{2}+(\mathrm{B} 8)^{2}}$ & Khan et al. 2005 \\
\hline S I & Salinity index I & $\frac{\mathrm{B}}{\mathrm{R}}$ & $\frac{\mathrm{B} 2}{\mathrm{~B} 4}$ & $\begin{array}{l}\text { Abbas and Khan } 2007 \\
\text { Abbas et al. } 2013\end{array}$ \\
\hline S II & Salinity index II & $\frac{B-R}{B+R}$ & $\frac{\mathrm{B} 2-\mathrm{B} 4}{\mathrm{~B} 2+\mathrm{B} 4}$ & $\begin{array}{l}\text { Abbas and Khan } 2007 \\
\text { Abbas et al. } 2013\end{array}$ \\
\hline S III & Salinity index III & $\frac{\mathrm{G} \times \mathrm{R}}{\mathrm{B}}$ & $\frac{\mathrm{B} 3 \times \mathrm{B} 4}{\mathrm{~B} 2}$ & $\begin{array}{l}\text { Abbas and Khan } 2007 \\
\text { Abbas et al. } 2013\end{array}$ \\
\hline S IV & Salinity index IV & $\frac{B \times R}{G}$ & $\frac{\mathrm{B} 2 \times \mathrm{B} 4}{\mathrm{~B} 3}$ & Abbas and Khan 2007 \\
\hline S V & Salinity index V & $\frac{\mathrm{R} \times \mathrm{NIR}}{\mathrm{G}}$ & $\frac{\mathrm{B} 4 \times \mathrm{B} 8}{\mathrm{~B} 3}$ & Abbas and Khan 2007 \\
\hline S VI & Salinity index VI & $\frac{G+R+N I R}{2}$ & $\frac{\mathrm{B} 3+\mathrm{B} 4+\mathrm{B} 8}{2}$ & Douaoui et al. 2006 \\
\hline S VII & Salinity index VII & $\frac{G+R}{2}$ & $\frac{B 3+B 4}{2}$ & Douaoui et al. 2006 \\
\hline S VIII & Salinity index VIII & $\frac{\text { SWIR1-SWIR2 }}{\text { SWIR1+SWIR2 }}$ & $\frac{\mathrm{B} 11-\mathrm{B} 12}{\mathrm{~B} 11+\mathrm{B} 12}$ & Bouaziz et al., 2011 \\
\hline S IX & Salinity index IX & $\frac{\text { SWIR1 }}{\text { SWIR2 }}$ & $\frac{\mathrm{B} 11}{\mathrm{~B} 12}$ & Bouaziz et al., 2011 \\
\hline NDVI & Normalized difference vegetation index & $\frac{\mathrm{NIR}-\mathrm{R}}{\mathrm{NIR}+\mathrm{R}}$ & $\frac{\mathrm{B} 8-\mathrm{B} 4}{\mathrm{~B} 8+\mathrm{B} 4}$ & Rouse et al. (1973) \\
\hline NDSI & Normalized difference salinity index & $\frac{\mathrm{R}-\mathrm{NIR}}{\mathrm{R}+\mathrm{NIR}}$ & $\frac{\mathrm{B} 4-\mathrm{B} 8}{\mathrm{~B} 4+\mathrm{B} 8}$ & Khan et al. (2005) \\
\hline
\end{tabular}

B, G, R, NIR, SWIR - blue, green, red, near-infrared, shortwave infrared bands, respectively. 
A regression analysis using the least-squares method was used to analyze a correlation between soil salinity and the calculated spectral indices values. This method proved to be very effective in studying various soil properties, in particular, salinization (Farifteh, 2007; Sidike et al., 2014; Peng et al., 2014; Wang et al., 2019). A linear, quadratic, exponential, logarithmic, and cubic functions was used to achieve the best statistical relation.

Prediction accuracy was evaluated according to $\mathrm{R}^{2}$, RMSE (Root Mean Square Error), RPD (residual prediction deviation) values. The $\mathrm{R}^{2}$ was determined by the following classification (Vaudour et al., 2019): models with $\mathrm{R}^{2}<0.4$ show a poor or very low level of predictive ability; values of $0.5<\mathrm{R}^{2}<0.7$ indicate models with an average level of forecasting; models with $\mathrm{R}^{2}>0.7$ are highly predictive.

The RPD values were calculated by the classification Chang et al. (2001) and Viscarra-Rossel et al. (2006), where RPD values $<1.0$ indicate a poor predictive model; $1.0<\mathrm{RPD}<1.4$ indicate a weak model; $1.4<$ RPD $<1.8$ indicate a good model that can be used for evaluation; $1.8<\mathrm{RPD}<2.0$ indicate a good model; $2.0<$ $\mathrm{RPD}<2.5$ show a very good model and values RPD $>2.5$ indicate the excellent quality of the predicted model.

Statistical data processing and correlation analysis were performed using Python programming language, in the Jupyter Notebook web-based interactive computational environment using pandas, matplotlib, NumPy, seaborn, sklearn libraries.

\section{Results and discussion}

General statistics of dry residue including mean, minimum, maximum, standard deviation (SD), and coefficient of variation (CV) are shown in Table 4. Dry residue of soils changed in a wide range from 0.02 to $5.5 \%$, which characterizes the degree of salinity from non-saline to extremely saline. The values of the Pearson correlation between the dry residue of soils and spectral indices also changed in a wide range (Fig. 2).

The Salinity index III $(G \times R) / B$ shows the best values of Pearson correlation $(\mathrm{R}=0.84)$. The Salinity Index III showed good results for some other soils in Pakistan ( $\mathrm{R}=0.64-0.82$ ) (Abbas et al., 2013) and somewhat worse for Saudi Arabia $(R=0.2-0.5)$ (Allbed et al., 2014).

Widely used approaches of remote assessment of soil salinization according to data of the vegetation index NDVI were unacceptable in the investigated area, as the correlation of this index with the dry residue of soil was not observed $(\mathrm{R}=-0.11)$. It is caused by weak development or dried up vegetation state.
Similarly, unsatisfactory results of this index were obtained on the territory of Algeria $(\mathrm{R}=0.00)$ (Douaoui et al., 2006); on a site in northeastern Brazil ( $\mathrm{R}=0.23$ ) (Bouaziz et al., 2011); in the Takla-Makan desert region (China) $(\mathrm{R}=-0.29)$ (Peng et al., 2019). In works (Fernandez-Buces et al., 2006; Pankova, 2015; Chi et al., 2019; Wang et al., 2019) it is shown that at soil surface not occupied by vegetation the correlation between vegetation indices and salinization is absent, and for soils with halophytic vegetation - weak.

In addition to the salinity index III, good mapping potential was identified in indices using visible bands. Salinity index 2, Salinity index 4 and Salinity index VII, using visible spectral bands, also showed good results for mapping $(\mathrm{R}=0.80)$. Salinity index VI with the NIR channel in the equation received a similar coefficient of correlation ( $\mathrm{R}=0.77$ ). Consequently, when vegetation is absent or underdeveloped, a good correlation is observed with indices based on the sum or multiplication of channels in visible and near-infrared spectral zones. The more soil saline content, the higher is its spectral reflectance in visible and nearinfrared bands. This is confirmed in studies (Abbas et al., 2013; Allbed et al., 2014; Sidike, 2014; Pankova et al., 2017; Wang et al., 2019). However, the indices constructed using short-wave infrared channels (SWIR), as in (Bouaziz et al., 2011), have not shown good results.

The closest relation between the salt content and reflectivity, with changes in salt content from 0.2 to $5.5 \%$ and pixel values from 0.08 to 0.20 was found for the Salinity index III $(G \times R) / B$. In these parameter limits, the dependence is described by the quadratic equation $\mathrm{y}^{\wedge}=-0.0057 \mathrm{x}^{2}+0.0462 \mathrm{x}+0.1011$, at correlation coefficients $\mathrm{R}=0.89, \mathrm{R}^{2}=0.79$ (Fig. 3 ).

This equation clearly shows the physical sense of dependence. At the concentration of salts to the average level (up to $0.75 \%$ ) pixel values change from 0 to 0.14 . With a further increase in salt concentration, they gradually grow. Also, at ex-

\section{Table 4}

Statistical description of dry residue

\begin{tabular}{ll}
\hline Statistical Parameter & Dry residue (\%) \\
\hline $\mathrm{n}=52$ & \\
Mean & 0.98 \\
Min & 0.02 \\
Max & 5.5 \\
SD & 1.45 \\
CV & 1.47 \\
\hline
\end{tabular}

\begin{tabular}{|c|c|c|c|c|c|c|c|c|c|c|c|c|c|c|c|}
\hline Si 1 & Si 2 & Si 3 & Si 4 & $\mathrm{BI}$ & SI & S II & S III & SIV & SV & SVI & S VII & S VIII & SIX & NDSI & I NDVI \\
\hline 0.77 & 0.80 & 0.76 & 0.80 & 0.74 & -0.43 & -0.44 & 0.84 & 0.72 & 0.59 & 0.77 & 0.80 & -0.07 & -0.08 & 0.62 & -0.11 \\
\hline
\end{tabular}

Fig. 2. The Pearson correlation graph of dry residue and calculated spectral indices 


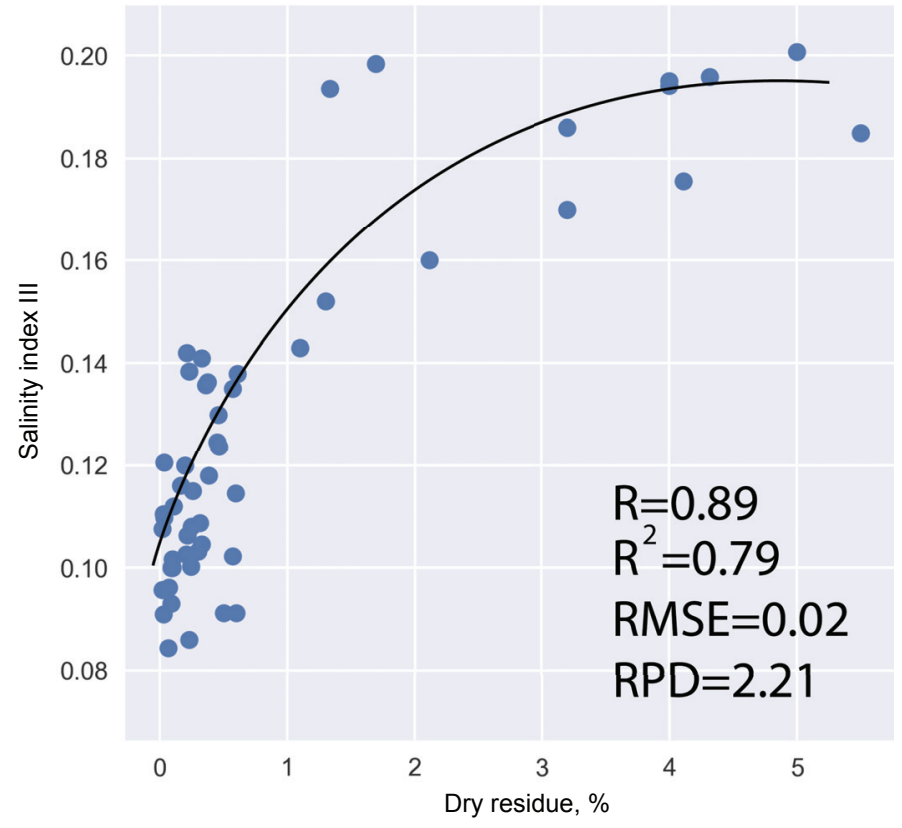

Fig. 3. Graph of correlation between values of Salinity index III and dry residue treme salinization $(>2 \%$ ) the parabola curve reaches a plateau, limited by the values of the reflectivity.

The Salinity index III, according to the classification, characterizes a very good level of the predictive model. Based on the obtained regression equation, the salinization map was created (Fig. 4).

The map allowed identifying the spatial distribution and areas of saline soils. Most of the territory is occupied by unsalted soils - 3230.5 ha $(64.8 \%$ ) (Table 5$)$. The saline soils (degree from moderately to extremely) are 875.8 ha $(17,6 \%)$ and locat-

Table 5

Distribution of saline soils

\begin{tabular}{llll}
\hline № & Salinity degree & Square, ha & $\%$ \\
\hline 1 & Non-saline & 3230.5 & 64.8 \\
2 & Slightly & 874.7 & 17.6 \\
3 & Moderately & 646.1 & 13 \\
4 & Highly & 163.4 & 3.3 \\
5 & Extremely & 66.3 & 1.3 \\
Total & & 4981 & 100 \\
\hline
\end{tabular}

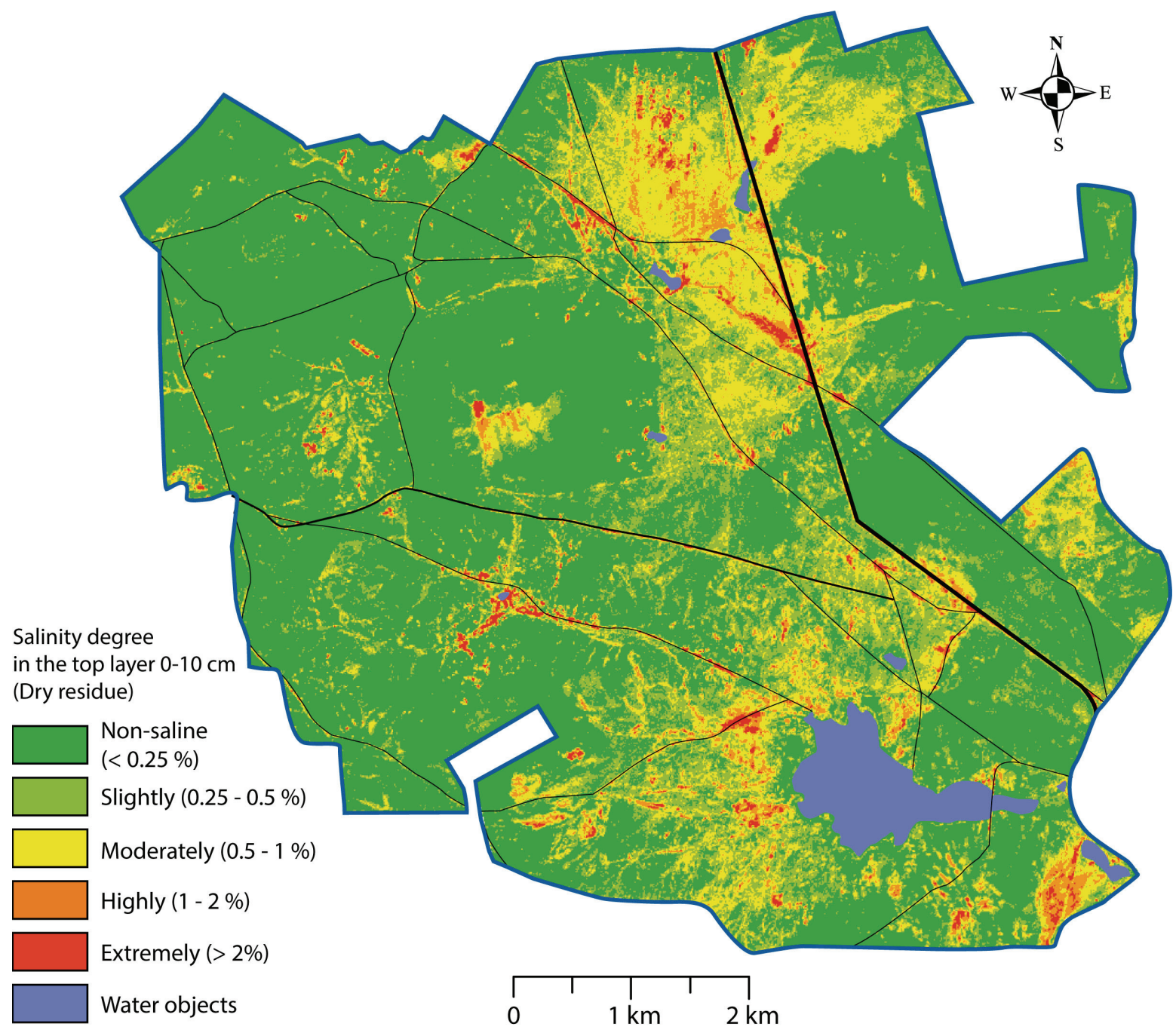

Fig. 4. Salinity map based on salinity index III 
ed around reservoirs, ponds, desiccated hollows of lakes and ponds, near rivers. These areas are characterized by an increase of a groundwater level. The solonchaks are hydromorphic soils and are characterized by an increased level of humidity in this region (Bulchuk, 1973). The arid climate and its changes (increase in temperature, reduced precipitation) significantly affect the active evaporation of groundwater. Under such conditions, easily soluble salts rise to a surface (Kovda, 1989; Gorbachev et al., 2012). This process also occurs in some places along the roads, as moisture accumulates here due to the features of their construction (low relief along roads). These areas are characterized by an increased salinity, and absence or depressed vegetation.

\section{Conclusions}

Nowadays, one of the main problems concerning saline soils in Russia is their evaluation, accounting, and monitoring. Due to the increase in anthropogenic influence and aridization of climate, correction and updating of soil maps with the use of remote sensing methods and GIS become relevant.

The use of Sentinel-2A satellite data demonstrated good possibilities and challenges for mapping saline soils. A quadratic statistical relation using the least-squares method resulted in the best performance correlation between soil salinity and calculated spectral indices values. For mapping saline soils in the Trans-Ural steppe zone, the most expedient is to use salinity index III, based on the channels of visible bands (red, blue, green). It allows to quickly detect, calculate areas and create salinity maps not only of the studied area, but also of the entire territory of the Trans-Ural steppe zone.

\section{Acknowledgments}

The reported study was funded by RFBR, project number 19-34-90001, and was performed within the framework of state assignment of the Ministry of Education and Science of the Russian Federation № 075-00326-19-00 on topic № AAAAA18-118022190102-3. Part of the results was obtained using the equipment of the Regional Center for Collective Use "Agidel".

\section{References}

Abbas, A., Khan, S., Hussain, N., Hanjra, M.A., Akbar, S., 2013. Characterizing soil salinity in irrigated agriculture using a remote sensing approach. Physics and Chemistry of the Earth Parts A/B/C 55(57), 43-52. https://doi.org/10.1016/j.pce.2010.12.004

Abbas, A., Khan S., 2007. Using remote sensing techniques for appraisal of irrigated soil salinity. [In]: MODSIM 2007: International Congress on Modelling and Simulation: Land, Water and Environmental Management: Integrated Systems for Sustainability 2632-2638.

Abdrakhmanov, R.F., Popov, V.G., 2010. Geochemistry and groundwater formation in the South Urals. RAS. Ufa: Gilem Publishing House. (in Russian)

Abuelgasim, A., Ammad, R., 2019. Mapping soil salinity in arid and semi-arid regions using Landsat 8 OLI satellite data. Remote Sensing Applications: Society and Environment 13, 415-425. https://doi. org/10.1016/j.rsase.2018.12.010
Allbed, A., Kumar, L., Aldakheel, Y.Y., 2014. Assessing soil salinity using soil salinity and vegetation indices derived from IKONOS high-spatial resolution imageries: Applications in a date palm dominated region. Geoderma 230(231), 1-8. https://doi.org/10.1016/ j.geoderma.2014.03.025

Allbed, A., Kumar, L., 2013. Soil salinity mapping and monitoring in arid and semi-Arid regions using remote sensing technology: a review. Advanced Remote Sensing 2(4), 373-385. https://doi.org/10.1016/ j.rsase.2018.12.010

Balyuk, S.A., Drozd, E.N., Naidenova, O.E., Nosonenko, A.A., 2019. Assessment of Provisioning Ecosystem Services of Irrigated Salt-Affected Soils in Ukraine. Eurasian Soil Science 52(4), 436-447. https://doi. org/10.1134/S1064229319040045

Bouaziz, M., Matschullat, J., Gloaguen, R., 2011. Improved remote sensing detection of soil salinity from a semi-arid climate in Northeast Brazil. Comptes Rendus Geoscience 343(11-12), 795-803. https://doi. org/10.1016/j.crte.2011.09.003

Bulchuk, P.Y., 1966. Solontsy and saline soils of Bashkir Urals. Bashkir Research Institute of Agriculture Science 2, 26-52. (in Russian)

Bulchuk, P.Y., 1973. Solontsy, saline i solonchak soils. Soils of Bashkiria. Vol. 1. Ufa. p. 350-383. (in Russian)

Chi, Y., Sun, J., Liu, W., Wang, J., Zhao, M., 2019. Mapping coastal wetland soil salinity in different seasons using an improved comprehensive land surface factor system. Ecological Indicators. 107(105517), 1-13. https://doi.org/10.1016/j.ecolind.2019.105517

Chang, C.-W., Laird, D., Mausbach, M., Hurburgh, C., 2001. Near-Infrared Reflectance Spectroscopy-Principal Components Regression Analyses of Soil Properties. Soil Science Society of America Journal 65(2), 480-490. https://doi.org/10.2136/sssaj2001.652480x

Douaoui, A., Nicolas, H., Walter, C., 2006. Detecting salinity hazards within a semiarid context by means of combining soil and remotesensing data. Geoderma 134(1-2), 217-230. https://doi.org/10.1016/ j.geoderma.2005.10.009

Farifteh, J., Van der Meer, F., Atzberger, C., Carranza, E.J.M., 2007. Quantitative analysis of salt-a ected soil reflectance spectra: a comparison of two adaptive methods (PLSR and ANN). Remote Sensing of Environment 110(1), 59-78. https://doi.org/10.1016/j.rse.2007.02.005

Fernández-Buces, N., Siebe, C., Cram, S., Palacio, J.L., 2006. Mapping soil salinity using a combined spectral response index for bare soil and vegetation: a case study in the former lake Texcoco, Mexico. Journal of Arid Environments 65(4), 644-667. https://doi.org/10.1016/ j.jaridenv.2005.08.005

Gabbasova, I.M., Suleimanov, R.R., 2007. Transformation of gray forest soils upon technogenic salinization and alkalization and subsequent rehabilitation in oil-producing regions of the southern Urals. Eurasian Soil Science 40(9), 1000-1007. https://doi.org/10.1134/ S1064229307090116

Gabbasova, I.M., Suleymanov, R.R., Garipov T.T., 2013. Degradation and remediation of soils polluted with oil-field wastewater. Eurasian Soil Science 46(2), 204-211. https://doi.org/10.1134/S1064229313020051

Gabbasova, I.M., Suleymanov, R.R., Sitdikov, R.N., Garipov, T.T., Komissarov, A.V., 2006. The effect of long-term irrigation on the properties of leached chernozems in the forest-steppe of the southern Cis-Ural region. Eurasian Soil Science 39(3), 283-289. https://doi.org/10.1134/ S1064229306030070

Gabbasova, I.M., Garipov, T.T., Komissarov, M.A., Suleimanov, R.R., Suyundukov, Ya.T., Khasanova, R.F., Sidorova, L.V., Komissarov, A.V., Suleimanov, A.R., Nazyrova, F.I., 2019. The Impact of Fires on the Properties of Steppe Soils in the Trans-Ural Region. Eurasian Soil Science 52(12), 1598-1607. https://doi.org/10.1134/S1064229319120044

Gorbachev, V.N., Babintseva, R.M., Karpenko, L.V., Karpenko, V.D., 2012. Negative impact of large reservoirs on the environment. Ulyanovsk Medical and Biological Journal 2, 7-16 (in Russian).

Gorji, T., Sertel, E., Tanik, A., 2017. Monitoring soil salinity via remote sensing technology under data scarce conditions: a case study from 
Turkey. Ecological Indicators 74, 384-391. https://doi.org/10.1016/ j.ecolind.2016.11.043

Gorokhova, I.N., Khitrov, N.B., Prokop’eva, K.O., Kharlanov, V.A., 2018. Soil Cover of the Svetloyarsk Irrigation System after 50 Years of Reclamation Practices. Eurasian Soil Science 51(8), 965-975. https://doi. org/10.1134/S1064229318060078

Ivushkin, K., Bartholomeus, H., Bregt, A.K., Pulatov, A., Bui, E.N., Wilford, J., 2018. Soil salinity assessment through satellite thermography for different irrigated and rainfed crops. International Journal of Applied Earth Observation and Geoinformation 68, 230-237. https:// doi.org/10.1016/j.jag.2018.02.004

Kattsov, V.M., editor. 2017. Report on climate risks in the Russian Federation. Saint Petersburg. (in Russian)

Khan, N.M., Rastoskuev, V.V., Sato, Y., Shiozawa, S., 2005. Assessment of hydrosaline land degradation by using a simple approach of remote sensing indicators. Agricultural Water Management 77(1-3), 96-109. https://doi.org/10.1016/j.agwat.2004.09.038

Khaziev, F.Kh., editor. 1995. Soils of Bashkortostan. Vol. 1. Ecologic-Genetic and Agroproductive Characterization. Ufa: Gilem. (in Russian)

Khaziev, F.Kh., Gabbasova, I.M., Khakimov, V.U., 2001. Influence of oilfield wastewater on agrochemical properties and biological activity of typical black soil. Eurasian Soil Science. 1, 85-93. (in Russian)

Khitrov, N.B., Chernikov, E.A., Popova, V.P., Fomenko, T.G., 2016. Factors and mechanisms of soil salinization under vineyards of southern Taman. Eurasian Soil Science 49(11), 1228-1240.

Komissarov, A., Safin, Kh., Ishbulatov, M., Khafizov, A., Komissarov, M., 2019. Irrigation as means to reduce the risks of agricultural production in the South Ural. Bulgarian Journal of Agricultural Science 25(Suppl. 2), 149-157.

Kovda, V.A., 1989. Soil pathology and planet biosphere protection. Pushchino. (in Russian)

Masoud, A.A., Koike, K., Atwia, M.G., El-Horiny, M.M., Gemail, K.S., 2019. Mapping soil salinity using spectral mixture analysis of landsat $8 \mathrm{OLI}$ images to identify factors influencing salinization in an arid region. International Journal of Applied Earth Observation and Geoinformation 83 (101944), 1-16. https://doi.org/10.1016/j.jag.2019.101944

Mamontov, V.G., 2002. Interpretation of water extraction data from saline soils. Methodical manual. Moscow: A.K. Timiryazev Agricultural Academy.

Metternichet, G.I., Zinck, J.A., 2003. Remote sensing of soil salinity: potential and constraints. Remote Sensing of Environment 85, 1-20. https:// doi.org/10.1016/S0034-4257(02)00188-8

Mulder,V.L., De Bruin, S., Schaepman, M.E., Mayr, T.R., 2011. The use of remote sensing in soil and terrain mapping - A review. Geoderma 162, 1-19. https://doi.org/10.1016/j.geoderma.2010.12.018

Pankova, E.I., et al. Salt-Affected Soils of Russia. 2006. Akademkniga, Moscow. (in Russian).

Pankova, E.I., 2015. Salt-affected soils of Russia: Solved and unsolved problems. Eurasian Soil Science 48(2), 115-127. https://doi.org/10.1134/ S106422931502009X
Pankova, E.I., Konyushkova, M.V., Gorokhova, I.N., 2017. On the problem of soil salinity assessment and the methodology of large-scale digital mapping of saline soils. Ecosystems: ecology and dynamics 1(1), 26-54. (in Russian)

Peng, J., Xiang, H., Guo, Y., Shi, Z., 2014. Comparative study on hyperspectral inversion accuracy of soil salt content and electrical conductivity. Spectroscopy And Spectral Analysis 34(2), 510-514. https://doi. org/10.3964/j.issn.1000-0593(2014)02-0510-05

Rosreestr. Information on Availability and Distribution of Land in the Russian Federation as of 01.01.2018 (by Subjects of the Russian Federation). Available from: https://rosreestr.ru/site/activity/sostoyaniezemel-ossii/gosudarstvennyy-natsionalnyy-doklad-o-sostoyanii-i-ispolzovanii-zemel-v-rossiyskoy-federatsii/

Rouse, J.W., Haas, R.H., Schell, J.A., Deering, D.W., 1974. Monitoring vegetation systems in the Great Plains with ERTS. In: Proceedings of the 3rd ERTS Symposium. Washington, USA.

Savin, I.Yu., Zhogolev, A.V., Prudnikova, E.Yu., 2019. Modern Trends and Problems of Soil Mapping. Eurasian Soil Science 52(5), 471-480. https://doi.org/10.1134/S1064229319050107

Sidike, A., Zhao, S., Wen, Y., Estimating soil salinity in Pingluo County of China using Quick Bird data and soil reflectance spectra. 2014. International Journal of Applied Earth Observation and Geoinformation 26, 156-175. https://doi.org/10.1016/j.jag.2013.06.002

Sobol, N.V., Gabbasova, I.M., Komissarov, M.A., 2015. Impact of climate changes on erosion processes in Republic of Bashkortostan. Arid Ecosystems 5(4), 216-221. https://doi.org/10.1134/S2079096115040137

Taghadosi, M.M., Hasanlou, M., Eftekhari, K., 2019. Retrieval of soil salinity from Sentinel-2 multispectral imagery. European Journal of Remote Sensing 52(1), 138-154. https://doi.org/10.1080/22797254.201 9.1571870

Vaudour, E., Gomez, C., Fouad, Y., Lagacherie, P., 2019. Sentinel-2 image capacities to predict common topsoil properties of temperate and Mediterranean agroecosystems. Remote Sensing of Environment 223, 21-33. https://doi.org/10.1016/j.rse.2019.01.006

Viscarra Rossel, R.A., Walvoort, D.J.J., McBratney, A.B., Janik, L.J., Skjemstad, J.O., 2006. Visible, near infrared, mid infrared or combined diffuse reflectance spectroscopy for simultaneous assessment of various soil properties. Geoderma 131(1), 59-75. https://doi.org/10.1016/ j.geoderma.2005.03.007

Wang, J. et al., 2019. Capability of Sentinel-2 MSI data for monitoring and mapping of soil salinity in dry and wet seasons in the Ebinur Lake region, Xinjiang, China. Geoderma 353, 172-187. https://doi.org/10.1016/ j.geoderma.2019.06.040

Wu, W., Mhaimeed, A.S., Al-Shafie, W.M., Ziadat, F., Dhehibi, B., Nangia, V., De Pauw, E., 2014. Mapping soil salinity changes using remote sensing in Central Iraq. Geoderma Regional 2(3), 21-31. https://doi. org/10.1016/j.geodrs.2014.09.002 